LETTER TO JMG

\title{
Detection of cell free placental DNA in maternal plasma: direct evidence from three cases of confined placental mosaicism
}

\author{
H Masuzaki, K Miura, K-i Yoshiura, S Yoshimura, N Niikawa, T Ishimaru
}

J Med Genet 2004;41:289-292. doi: 10.1136/jmg.2003.015784

$\mathrm{F}$ etal cells are consistently found in the maternal circulation, and polymerase chain reaction based studies have led to the identification of cell free fetal DNA (fetal DNA) in maternal blood. Approximately 1.2 nucleated fetal cells $/ \mathrm{ml}$ of whole blood from women carrying a male fetus were detectable, ${ }^{1}$ and relative enrichment of fetal DNA was detected in the maternal plasma and serum. ${ }^{2}$ The amount of fetal DNA in the maternal blood increases with progression of pregnancy, and $3.4-6.2 \%$ of the total maternal plasma DNA during pregnancy was of fetal origin. ${ }^{3}$ Therefore, cell free fetal DNA in pregnant women's plasma is useful for noninvasive prenatal diagnosis, especially for detection of fetal sex, ${ }^{34} \mathrm{RhD}$ blood type, ${ }^{5-7}$ and gene mutations of paternal origin. ${ }^{8-10}$ Previous studies indicated that pregnant women with pre-eclampsia, ${ }^{11}$ placenta previa ${ }^{12}$ and fetal chromosome abnormalities $^{13}$ tend to have elevated levels of fetal DNA in their plasma. Since functional or structural abnormalities of the placenta and destruction of the trophoblast may be associated with these diseases, ${ }^{14}$ it is suggested that cell free fetal DNA is of placental origin. This implies that quantitative analysis of fetal DNA may be valuable to screen for placental dysfunction. $\mathrm{Ng}$ et $\mathrm{al}^{15}$ recently reported that placental mRNA is present in the maternal circulation, and suggested that the same might occur for placental DNA, ${ }^{16}$ However, no direct evidence has been given for placenta derived cell free fetal DNA in the maternal blood, although its clinical use is growing. ${ }^{17}$

Confined placental mosaicism, which is defined by the presence of abnormal karyotypes only in the placenta while the fetus itself is usually diploid, ${ }^{18}$ may occur through a loss of the extra chromosome in a trisomic zygote during an early mitotic cell division in only the embryonic progenitor cells (trisomic rescue) or through a postzygotic mitotic duplication of one chromosome in only the progenitors of the placenta cell lineage in the developing normal diploid conceptus. ${ }^{18}$ Confined placental mosaicism has been reported to be detected in $1-2 \%$ of chorionic villus samples at $10-11$ weeks

\section{Key points}

- Cell free fetal DNA released into maternal plasma is useful for non-invasive prenatal diagnosis, but no definitive evidence has been provided for its origin.

- We analysed parent-child transmission patterns of alleles at various dinucleotide repeat polymorphism loci in nine cases of confined placental mosaicism, which is defined by the presence of abnormal karyotypes in only the placenta.

- Diploid cells in three of the nine neonates with confined placental mosaicism had one each of parental alleles, whereas trisomic cells in their placentas contained one maternal and two paternal alleles. In all of them, one paternal allele that was absent in the neonates was present both in trisomic cells of the placenta and in cell free DNA from maternal plasma.

- Our results not only provide direct evidence for the presence of placental DNA in maternal plasma but also indicate possible usefulness of such DNA for noninvasive prenatal diagnosis of genetic diseases and screening for placental dysfunction.

of gestation, ${ }^{18}$ and in over $20 \%$ of pregnancies with intrauterine growth retardation of unknown cause. ${ }^{19}$

If a trisomic allele is detected in maternal plasma with confined placental mosaicism, this is direct evidence for placental DNA in the maternal circulation. Here we report the result of a study that supports the presence of placental DNA in maternal plasma.

Abbreviation: fetal DNA, cell free fetal DNA

Table 1 Parent-child allele transmission

\begin{tabular}{|c|c|c|c|c|c|c|c|c|}
\hline \multirow[b]{2}{*}{ Case } & \multirow{2}{*}{$\begin{array}{l}\text { Marker } \\
\text { used }\end{array}$} & \multicolumn{6}{|c|}{ Genotype in } & \multirow[b]{2}{*}{ Karyotype of placenta } \\
\hline & & Father & Mother & Neonate & Placenta & MP1 & MP2 & \\
\hline 4 & D22S280 & 2,3 & 1,4 & 2,4 & $2,3,4$ & $1,2,3,4$ & 1,4 & $46, X X(10) / 47, X X,+22(40)$ \\
\hline 5 & D7S640 & 2,3 & 1,4 & 1,2 & $1, \overline{2}, 3$ & $1,2, \overline{3}, 4$ & 1,4 & $46, X X(16) / 47, X X,+7(34)$ \\
\hline 6 & D2S337 & 1,2 & 3,4 & 1,4 & $1,2, \overline{4}$ & $1,2, \overline{3}, 4$ & 3,4 & $46, X Y(8) / 47, X Y,+2(42)$ \\
\hline
\end{tabular}

Allele number is defined according to the order of its size.

MP1 and MP2 indicate maternal plasma before and after delivery, respectively.

Bold and underlined numbers are paternally derived alleles seen in the placenta but missing in neonates.

Alleles seen in maternal plasma but absent in both neonate and placenta come from maternal blood DNA 


\section{MATERIALS AND METHODS}

\section{Clinical samples}

To identify confined placental mosaicism cases, we first screened 50 women whose infants had intra-uterine growth retardation (birthweight $<5$ th percentile for gestational age) of unknown cause. Routine screening of other risk factors for intra-uterine growth retardation (for example, fetal infection, TORCH syndrome, pre-eclampsia, or cord factors) was negative in all cases. Neonatal and parental blood was collected and tissue samples were obtained from at least two sites of the placenta at delivery. Standard karyotyping was then carried out. Cellular DNA was extracted from leucocytes of the neonates and their parents, and cell free DNA was collected from maternal plasma $(1.6 \mathrm{ml})$ before delivery and one month after delivery, using a Qiagen blood mini kit (Qiagen, Hilden, Germany). Placental DNA was extracted
A

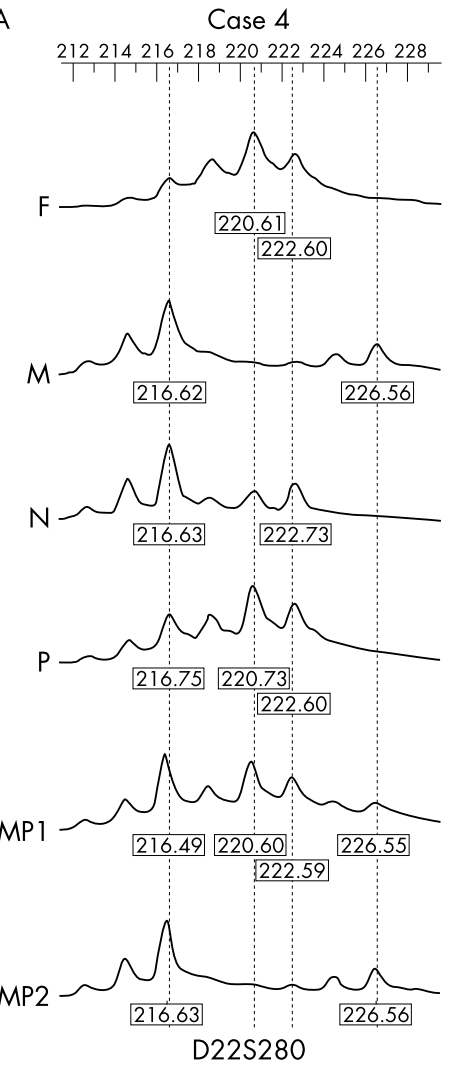

B

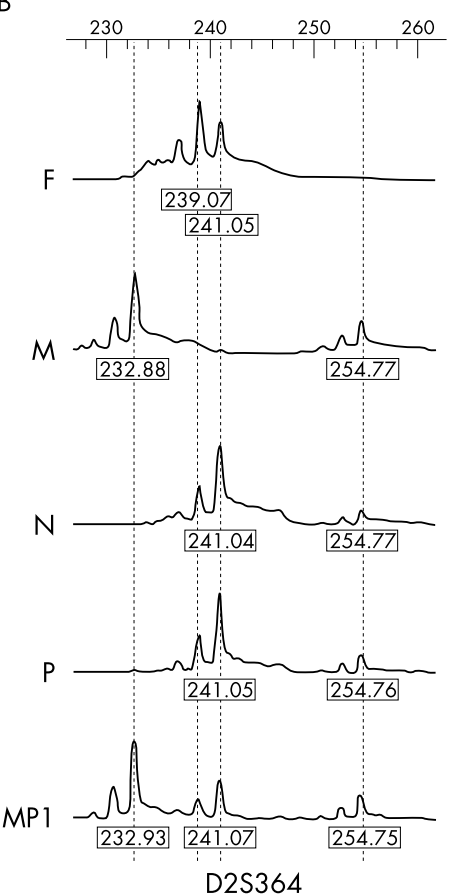

Case 5
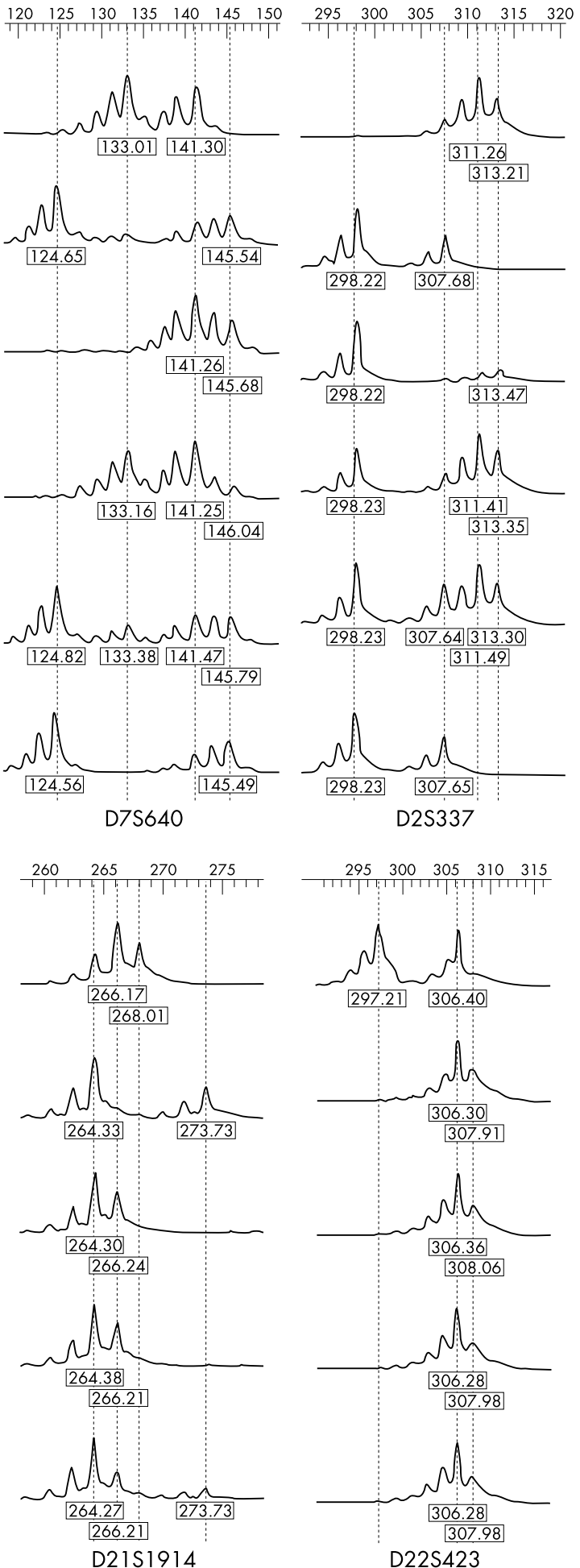

Figure 1 Allelotypes of father $(F)$, mother $(M)$, neonate with intra-uterine growth retardation $(N)$, placenta $(P)$, and maternal plasma before delivery (MP1) and after delivery (MP2). Placentas of cases 4, 5, and 6 had confined placental mosaicism for trisomies 22, 7, and 2, respectively. 
after delivery. All these study protocols were approved by the Committee for the Ethical Issues on Human Genome and Gene Analysis in Nagasaki University, and written informed consent was obtained from all the women.

\section{Genotyping}

We genotyped DNA samples at various dinucleotide repeat polymorphism loci (ABI PRISM linkage mapping set MDI0, Applied Biosystems, Foster City, CA) using GeneAmp PCR System 9700 (Applied Biosystems). Each genotyping was repeated at least three times to avoid erroneous results. PCR was cycled 40 times at $95^{\circ} \mathrm{C}$ for $10 \mathrm{~s}, 55^{\circ} \mathrm{C}$ for $30 \mathrm{~s}$, and $72^{\circ} \mathrm{C}$ for $30 \mathrm{~s}$, in a $20 \mu \mathrm{l}$ mixture containing $50 \mathrm{ng}$ genomic DNA, $10 \mathrm{pM}$ of each fluorescent primer and reverse primer, $250 \mathrm{M}$ dNTP, $0.5 \mathrm{U}$ Ampli Taq Gold DNA polymerase (Applied Biosystems), and $10 \times$ PCR buffer (Applied Biosystems). PCR products were resolved on 5\% denaturing polyacrylamide gels using an ABI 377 DNA sequencer (Applied Biosystems). Genotypes were analysed using an ABI GeneScan 3.1.2 and Genotyper 2.5 software (Applied Biosystems). Sensitivity testing of the procedure performed prior to the PCR-based genotyping revealed that male specific alleles were clearly detected in a 1/1000:1/10 000 male:female DNA pool.

\section{RESULTS AND DISCUSSION}

Nine of the 50 cases examined were diagnosed to have confined placental mosaicism, which is defined as identification of the same aneuploidy in at least two separate cultures - that is, a normal karyotype in lymphocytes of the neonates with intra-uterine growth retardation, and a chromosome abnormality confined to their placentas. We then analysed DNA from the neonates, placentas, and parents to determine the origin of confined placental mosaicism. Three cases (Cases 4, 5, and 6) were informative; their confined placental mosaicism was composed of a normal diploid cell line and a cell line with trisomy for 22, 7 , or 2 , respectively (table 1). Cases 4 and 5 were primigravida, and case 6 was multiparous. Parent-child transmission patterns of polymorphic markers showed that diploid cells in all the three neonates had one of each parental allele, whereas trisomic cells in their placentas inherited one maternal and two paternal alleles. Markers used for analysis in the three cases were as follows: D22S420, D22S280, D22S423, D22S539, D22S274, D21S263, D21S1914, D20S195, D20S173, D19S209, D19S418, D7S540, D7S640, D7S513, D7S657, D7S516, D2S2333, D2S126, D2S325, D2S364, and D2S337. In case 4, four parental alleles at a polymorphic locus (D22S280) were detected: $220 \mathrm{bp}$ and $222 \mathrm{bp}$ alleles in the father, and $216 \mathrm{bp}$ and $226 \mathrm{bp}$ alleles in the mother (fig la). In the placenta of this case, three alleles $(216 \mathrm{bp}, 220 \mathrm{bp}$, and $222 \mathrm{bp})$ were identified - that is, one maternally derived (216 bp) and two paternally derived (220 bp and $222 \mathrm{bp}$ ) alleles, while in leucocytes of the neonate, only a maternal (216 bp) and a paternal (222 bp) allele were observed, the result confirming confined placental mosaicism. On the other hand, the $220 \mathrm{bp}$ allele that was absent in the neonate was detected in cell free DNA from prenatal maternal plasma before delivery, but disappeared in maternal plasma after delivery (fig la). Similar results were obtained in cases 5 and 6 at $D 7 S 640$ and D2S337, respectively (table 1, fig la): a paternal allele, which was present in the placenta with confined placental mosaicism but absent in neonates, was detected in maternal plasma DNA before delivery. Genotyping of 31 normal women as negative controls at the same marker loci showed normal disomic patterns (data not shown).

Paternal DNA contamination was excluded in these three cases by one paternal and one maternal allele transmissions to the fetal tissues at other loci on non-trisomic chromosomes, and by the lack of the paternal allele, which was absent in the neonate and placenta, in the maternal plasma sample for non-trisomic chromosomes (fig lb). Retention of fetal DNA derived from previous pregnancies in maternal plasma was unlikely, because such cell free fetal DNA generally disappears from the maternal circulation within two hours, as seen in our three cases (fig la), and its mean half life was reported to be $16.3 \mathrm{~min}^{2021}$ In addition, it was absolutely ruled out in cases 4 and 5, because they were primigravida. These results indicate that, in all three cases, a trisomic cell line of the placenta resulted from meiotic nondisjunction in the father, and one of two paternally derived chromosomes 22, 7, or 2 was subsequently lost (trisomic rescue) during an early somatic division, leading to a normal diploid cell line both in a subset of placental cells and in the neonatal cells. It is most likely that the paternally derived allele that was absent in the neonates but was detected in maternal plasma was derived from fetal DNA in the trisomic cells of the placenta. The results also provide direct evidence for the placental origin of cell free fetal DNA circulating in maternal blood, although a possibility that the results might only reflect pregnancies with confined placental mosaicism cannot be absolutely ruled out. Measurements of cell free DNA concentrations in maternal plasma may enable the placental status to be monitored during pregnancy. In other words, cell free fetal DNA in maternal plasma may become a useful material to investigate the function, characterisation, and development of the placenta during pregnancy. Also, our results showed that the presence of two paternal alleles in maternal plasma does not necessarily indicate the presence of two paternal alleles in a fetus.

An infant with intra-uterine growth retardation (case 5) was diagnosed as having Silver-Russell syndrome (MIM 180860). Although maternal uniparental disomy for chromosome 7 (UPD7) has been known to cause $10 \%$ of SilverRussell syndrome cases, ${ }^{22}$ such UPD was excluded in this case. Therefore, the infant's intra-uterine growth retardation may be attributed to other causes, probably to placental dysfunction.

In conclusion, the result of our study provides direct evidence for the release of placental DNA into the maternal circulation and suggests possible usefulness of such DNA for non-invasive prenatal diagnosis of genetic diseases and screening for placental dysfunction.

\section{ACKNOWLEDGEMENTS}

We thank Dr Joseph Wagstaff for his help and valuable advice.

\section{Authors' affiliations \\ H Masuzaki*, K Miura*, S Yoshimura, T Ishimaru, Department of Obstetrics and Gynecology, Graduate School of Biomedical Sciences, Nagasaki University, Nagasaki, Japan \\ K-i Yoshiura, N Niikawa, Department of Human Genetics, Graduate School of Biomedical Sciences, Nagasaki University, Nagasaki, Japan K-i Yoshiura, N Niikawa, CREST, Japan Science and Technology Agency (JST), Kawaguchi, Japan \\ *These authors contributed equally to this work \\ This work was supported in part by Grants-in-Aid for Scientific Research (Nos 15591761, 13671729, and 13854024) from the Ministry of Education, Sports, Culture, Science, and Technology of Japan. NN was supported in part by CREST, JST, Japan. \\ Conflicts of interest: none declared. \\ Correspondence to: K Miura, MD, PhD, Department of Obstetrics and Gynecology, Graduate School of Biomedical Sciences, Nagasaki University, 1-7-1 Sakamoto, Nagasaki 852-8501, Japan; \\ kiyonori@net.nagasaki-u.ac.jp}

Received 21 October 2003

Accepted for publication 15 December 2003 


\section{REFERENCES}

1 Bianchi DW, Williams JM, Sullivan LM, Hanson FW, Klinger KW, Shuber AP. PCR quantitation of fetal cells in maternal blood in normal and aneuploid pregnancies. Am J Hum Genet 1997:61:822-9.

2 Lo YM, Corbetta N, Chamberlain PF, Rai V, Sargent IL, Redman CW, Wainscoat JS. Presence of fetal DNA in maternal plasma and serum. Lancet 1997;350:485-7.

3 Lo YM, Tein MS, Lau TK, Haines CJ, Leung TN, Poon PM, Wainscoat JS, Johnson PJ, Chang AM, Hjelm NM. Quantitative analysis of fetal DNA in maternal plasma and serum: implications for noninvasive prenatal diagnosis. Am J Hum Genet 1998;62:768-75.

4 Sekizawa A, Kondo T, Iwasaki M, Watanabe A, Jimbo M, Saito H, Okai T. Accuracy of fetal gender determination by analysis of DNA in maternal plasma. Clin Chem 2001;47:1856-8.

5 Faas BH, Beuling EA, Christiaens GC, von dem Borne AE, van der Schoot CE. Detection of fetal RHD-specific sequences in maternal plasma. Lancet 1998;352:1196.

6 Lo YM, Hielm NM, Fidler C, Sargent IL, Murphy MF, Chamberlain PF, Poon PM, Redman CW, Wainscoat JS. Prenatal diagnosis of fetal RhD status by molecular analysis of maternal plasma. N Engl J Med 1998;339:1734-8.

7 Pertl B, Bianchi DW. Fetal DNA in maternal plasma: emerging clinical applications. Obstet Gynecol 2001;98:483-90.

8 Amicucci P, Gennarelli M, Novelli G, Dallapiccola B. Prenatal diagnosis of myotonic dystrophy using fetal DNA obtained from maternal plasma. Clin Chem 2000;46:301-2.

9 Chiu RW, Lau TK, Cheung PT, Gong ZQ, Leung TN, Lo YM. Noninvasive prenatal exclusion of congenital adrenal hyperplasia by maternal plasma analysis: a feasibility study. Clin Chem 2002;48:778-80.

10 Saito H, Sekizawa A, Morimoto T, Suzuki M, Yanaihara T. Prenatal DNA diagnosis of a single-gene disorder from maternal plasma. Lancet 2000;356:1170.
11 Leung TN, Zhang J, Lau TK, Chan LY, Lo YM. Increased maternal plasma fetal DNA concentrations in women who eventually develop preeclampsia. Clin Chem $2001 ; 47: 137-9$.

12 Sekizawa A, Jimbo M, Saito $H$, Iwasaki M, Sugito $Y$, Yukimoto $Y$, Otsuka J, Okai T. Increased cell-free fetal DNA in plasma of two women with invasive placenta. Clin Chem 2002;48:353-4.

13 Lo YM, Lau TK, Zhang J, Leung TN, Chang AM, Hjelm NM, Elmes RS, Bianchi DW. Increased fetal DNA concentrations in the plasma of pregnant women carrying fetuses with trisomy 21. Clin Chem 1999;45:1747-51.

14 Sekizawa A, Yokokawa K, Sugito Y, Iwasaki M, Yukimoto Y, Ichizuka K, Saito H, Okai T. Evaluation of bidirectional transfer of plasma DNA through placenta. Hum Genet 2003; 1 13:307-10.

15 Ng EK, Tsui NB, Lau TK, Leung TN, Chiu RW, Panesar NS, Lit LC, Chan KW, Lo YM. mRNA of placental origin is readily detectable in maternal plasma. Proc Natl Acad Sci U S A 2003;100:4748-53.

16 Ferguson-Smith MA. Placental mRNA in maternal plasma: prospects for fetal screening. Proc Natl Acad Sci U S A 2003;100:4360-2.

17 Bianchi DW, Lo YM. Fetomaternal cellular and plasma DNA trafficking: the Yin and the Yang. Ann N Y Acad Sci 2001 ;945:119-31.

18 Kalousek DK, Vekemans M. Confined placental mosaicism. J Med Genet 1996;33:529-33.

19 Lestou VS, Kalousek DK. Confined placental mosaicism and intrauterine fetal growth. Arch Dis Child Fetal Neonatal Ed 1998;79:F223-6.

20 Lo YM, Zhang J, Leung TN, Lau TK, Chang AM, Hielm NM. Rapid clearance of fetal DNA from maternal plasma. Am J Hum Genet 1999;64:218-24.

21 Angert RM, LeShane ES, Lo YM, Chan LY, Delli-Bovi LC, Bianchi DW. Fetal cell-free plasma DNA concentrations in maternal blood are stable 24 hours after collection: analysis of first- and third-trimester samples. Clin Chem 2003;49:195-8.

22 Joyce CA, Sharp A, Walker JM, Bullman H, Temple IK. Duplication of 7p12.1-p13, including GRBIO and IGFBPI, in a mother and daughter with features of Silver-Russell syndrome. Hum Genet 1999;105:273-280. 